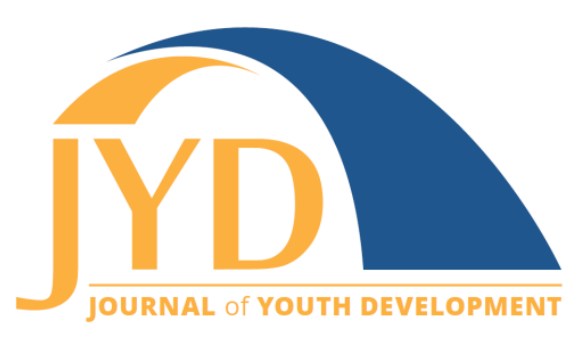

http://jyd.pitt.edu/ | Vol. 15 Issue 1 DOI 10.5195/jyd.2020.821 | ISSN 2325-4017 (online)

\title{
Sustaining Passion: Findings from an Exploratory Study of the OST Program Workforce
}

\author{
Georgia S. Hall \\ National Institute on Out-of-School Time, Wellesley College \\ ghall@wellesley.edu
}

Lisette DeSouza

National Institute on Out-of-School Time, Wellesley College

Idesouza@wellesley.edu

Elizabeth Starr

National Institute on Out-of-School Time, Wellesley College

estarr@wellesley.edu

Kathryn Wheeler

National Institute on Out-of-School Time, Wellesley College

katie.wheeler@wellesley.edu

\section{Kathy Schleyer}

National Institute on Out-of-School Time, Wellesley College

kschleyer@wellesley.edu

\begin{abstract}
It has long been understood that high-quality staffing is a major contributor to achieving positive outcomes for children and youth in out-of-school time (OST) programs. Yet, information on the current OST program workforce is outdated and understudied. The purpose of this study was to explore, via a convenience sample of OST program workers, the perceived features of the OST field and the relative importance of these features to workers in the field. The researchers were particularly interested in OST worker perception of features that may typically be associated with longevity in a profession. Improving understanding of the perceptions of the OST workforce may help employers to foster the work environments, staffing structures, compensation approaches, and professional development experiences that influence high-quality workers to stay in the field. The study findings illuminate the significance that workers in the OST field attach to passion for a field of work, and the central importance to them of building relationships with and fostering positive and healthy development for children.
\end{abstract}

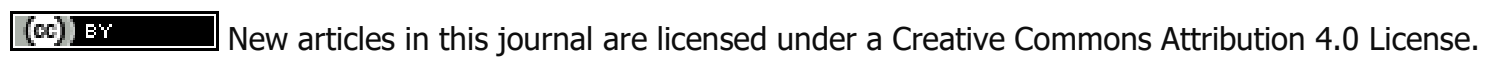
This journal is published by the University Library System, University of Pittsburgh and is cosponsored by the University of Pittsburgh Press. The Journal of Youth Development is the official peer-reviewed publication of the National Association of Extension 4-H Youth Development Professionals and the National AfterSchool Association. 


\section{Sustaining Passion: OST Program Workforce}

Key words: out-of-school time programs, workforce, survey, longevity, passion

\section{Introduction and Background}

While providing care and safety has historically been a major focus of after-school programs, today programs often offer a broad array of learning and enrichment activities with goals to support academic and social-emotional skill-building. It has long been understood that highquality staffing is a major contributor to achieving positive outcomes for children and youth in out-of-school time (OST) ${ }^{1}$ programs (Commission on Children at Risk, 2003; Curry et al., 2009; Gable \& Halliburton, 2003; Knoche, Peterson, Edwards, \& Jeon, 2006; Miller \& Hall, 2007). Having a good understanding of the OST workforce, its characteristics, needs, attitudes, and values helps to inform effective approaches for recruiting, developing, and retaining quality workers.

Previous studies have shown that the OST workforce presents a diverse profile (Yohalem \& Pittman, 2006; Yohalem, Pittman, \& Edwards, 2010) as related to age, background, level of education, and prior experience such that a "single cohesive description of the workforce cannot be constructed" (Nee, Howe, Schmidt \& Cole, 2006, p. 45). Several factors have been identified as persistent challenges to supporting and maintaining a productive and effective OST workforce. Lack of full-time work opportunities and low compensation have been at the forefront of reasons workers have reported for moving on from the field (Porter, 2012; Whitebook, Phillips, \& Howes, 2014; Yohalem \& Pittman, 2006; Yohalem et al., 2010).

Employment in the OST field is often seen as a stepping-stone to other careers with better pay, making it difficult to advocate for investment in workers who may take their skills elsewhere. Nee et al. (2006) reported that three quarters of OST workers age 25 or less, many with college degrees, expected to leave the field within 3 years. However, the OST field also does include a set of workers who are mostly full-time, have advanced degrees and are less prone to turnover (Nee et al., 2006). Yet, this set of workers may lack career advancement pathways that connect job opportunities, responsibilities, and compensation in a clear and systemic way. The most recent OST workforce survey conducted by the National AfterSchool Association (NAA) in 2013

\footnotetext{
${ }^{1}$ We substitute "out-of-school time" or OST for "after-school" to take a broader title for programs that take place during the out-of-school hours and include programs that take place before school, during school holidays, and during summer.
} 


\section{Sustaining Passion: OST Program Workforce}

found that $39 \%$ of its members had been with their current employer for more than 10 years (NAA, n.d.), suggesting a "core of workers with longevity" (Nee et al., 2006, pg. 5).

Most of our current understanding of workforce characteristics has been drawn from these two major workforce studies conducted by the Forum for Youth Investment in 2005 and NAA in 2013 (NAA, n.d.; Yohalem \& Pittman, 2006). Definite steps have been taken in the field to improve supports for the workforce including development of training, higher education, the creation of career pathways and ways to collect data such as workforce registries, along with attempts to improve compensation for workers.

However, a deeper and updated understanding of the OST workforce is crucial to supporting and sustaining the quality and impact of OST program learning experiences for America's children. Recent comments in a newly-released report by The Aspen Institute (2019) compel that while "considerable attention has been given on the social, emotional, and cognitive competencies of children and youth as well as the content and contexts that foster them . . . less attention has been given to the critical role of adults in creating rich, equitable learning environments or engaging with young people in the kinds of supportive relationships that ensure that all students achieve their fullest potential, regardless of background and circumstance" (p. 31). In order to fill this critical role and to stay engaged in the field, workers need to feel supported, well-trained, compensated, recognized, and hopeful. It is valuable to investigate how workers perceive the OST profession. How well do the features of the OST field align with workers' professional needs?

\section{Purpose}

The purpose of this study was to explore, via a convenience sample of OST program workers, the perceived features of the OST field and the relative importance of these features to workers in the field. The study was conducted by researchers from the National Institute on Out-ofSchool Time (NIOST) at Wellesley College. NIOST is an action-research institute that supports the healthy development of children, families, and communities, and advances the OST field through research, training, advocacy, and tools.

The researchers were particularly interested in OST worker perception of features that may typically be associated with longevity in a profession such as career advancement, high pay, favorable benefits, professional development, and flexible work schedules. Improving understanding of the perceptions of the OST workforce may help employers to foster the work 


\section{Sustaining Passion: OST Program Workforce}

environments, staffing structures, compensation approaches, and professional development experiences that influence high-quality workers to stay in the field.

Specific research questions were addressed:

1. What do current OST workers perceive as significant features of the OST field?

2. What do current OST workers report as important features of a field of employment to them and how available are these features in the OST field?

3. Through responses to open-ended questions, what do OST workers report regarding work satisfaction, challenge, and entry into the field?

\section{Method}

\section{Sample}

\section{Demographics}

The sample consisted of 342 participants. Most respondents completed demographic questions and $83 \%$ self-identified as female, $77 \%$ self-identified as White. Of the sample, $41 \%$ had a bachelor's degree and 32\% had a master's degree. Mean age was 40 years $(S D=13.3)$. As for income levels, $12 \%$ of respondents reported an income below $\$ 20,000 ; 48 \%$ between $\$ 21,000$ and $\$ 50,000 ; 21 \%$ between $\$ 50,001$ and $\$ 70,000 ; 10 \%$ between $\$ 70,001$ and $\$ 90,000$; and $9 \%$ over $\$ 90,000$.

\section{Work Characteristics}

Respondents reported working in the field for 9 years on average $(S D=8.1)$, with a median of 5.0 years. Most respondents (70\%) reported working full-time and 30\% reported working parttime. Directors, managers, supervisors, and coordinators comprised $73 \%$ of the sample and $10 \%$ were frontline staff. Participants reported working other jobs in the OST program field $(21 \%)$ and outside of the OST program field (38\%). Almost two thirds (60\%) of the sample reported doing unpaid work which contributes to their position.

\section{Geographic Background}

Approximately $33 \%$ of respondents said they work in a site located in a suburban area, $19 \%$ were in a rural area, and $49 \%$ in an urban area. Forty-five percent were from the Northeast, $9 \%$ from the South, $37 \%$ from the Midwest, and $8 \%$ from the West. 


\section{Sustaining Passion: OST Program Workforce}

\section{Procedure}

Data were collected over 3 weeks in January 2019. The survey was administered using Qualtrics XM (2019) and distributed using convenience and snowball sampling (Elliot, Fairweather, Olsen, \& Pampaka, 2016) through NIOST's communication channels including a mailing list, Facebook, and Twitter. NIOST maintains a mailing list of national level OST program leaders, researchers, practitioners, and other youth development professionals. Participants were invited to share the survey with peers in the OST program field working in and outside their organization. The study was approved by the IRB at Wellesley College. The survey was designed to be completed on average in 20 minutes. Median response time was 10 minutes.

\section{Measures}

Survey questions were developed based on a review of previous studies that have addressed OST and early childhood workforce issues (Morrow, 2000; NAA, n.d.; Whitebook, 1989; Whitebook et al., 2014; Yohalem \& Pittman, 2006; Yohalem et al., 2010). In addition, the questions were informed by the research team's collective professional knowledge of workforce trends and issues in the field. The survey was reviewed by the research team before being finalized for distribution. The survey consisted of 74 items grouped into three areas: (a) features of the OST field and their availability in the OST field; (b) the level of importance to the responder of perceived features of the OST field; and (c) open-ended responses regarding work satisfaction, challenge, and entry into the field.

\section{Data Analysis}

This exploratory study took a mixed-methods approach. In the quantitative section, individual indicators were analyzed descriptively. The qualitative data from the open-ended questions were coded thematically by question. Themes and categories were derived inductively and each piece of data had the potential to be coded in multiple categories. These data were analyzed by two members of the research team and consensus was built through discussion and revision with research team members. The quantitative and qualitative data are presented by thematic area to triangulate data about what is important to the members of the OST workforce who participated in this study. 


\section{Results}

\section{Workers' Perceptions of the Features of the OST Field}

Survey participants were presented with a list of possible work field features and asked how true these features were of their perception of the OST field. Participants pointed to the opportunity to work with children and youth as clear feature of OST work. Some of the features of a work field that may influence longevity and satisfaction in a career seemed less evident to workers and were rated between "A Little True" and "Mostly True" including fair pay, opportunity for advancement, and benefits (see Table 1).

\section{Table 1. Respondents' Average Scores on Perceptions of the OST Field}

How true is each of the following statements about the OST field?

\begin{tabular}{|l|c|c|}
\hline The OST field . . . & M & SD \\
\hline Provides opportunity to work with children and youth & 3.86 & 0.40 \\
\hline Provides opportunity to give back to a community & 3.44 & 0.72 \\
\hline Provides opportunity for challenging and exciting work & 3.34 & 0.72 \\
\hline Provides a lively environment, with socializing and collaboration & 3.28 & 0.76 \\
\hline Provides opportunity for professional development and learning & 3.09 & 0.78 \\
\hline Provides work flexibility related to days of the week and/or hours at work & 2.60 & 1.03 \\
\hline Provides opportunity for advancement or promotion & 2.40 & 0.92 \\
\hline Connects workers to benefits such as health care and education & 2.29 & 0.99 \\
\hline Provides fair pay & 2.23 & 0.97 \\
\hline
\end{tabular}

Note. $M=$ Mean, $S D=$ Standard deviation; 1 (Not true), 2 ( $A$ little true), 3 (Mostly true), 4 (Very true)

Appreciation of the opportunity to work with children was also evident in the open-response questions. Many respondents $(n=72)$ indicated that building relationships with children and seeing them change and grow up over time is valued most. Relationships become even more meaningful as they extend to family members. Two respondents commented:

I love the students. I have such a great relationship with them. They are the reason I come to work. $(41, \mathrm{~F}, \mathrm{PT})^{2}$

\footnotetext{
${ }^{2}$ Age in years, Male or Female, Full-time or Part-time
} 


\section{Sustaining Passion: OST Program Workforce}

I am able to be part of the [children's] lives and their families daily . . . I will cherish this for the rest of my life. Not only do I have my own family, but other families I work with say I'm part of theirs. They come back and invite me to graduations and other family celebrations. I am able to take that with me and the feeling is tremendous. $(54, \mathrm{~F}, \mathrm{FT})$

Some respondents $(n=19)$ noted that they feel a sense of connection and camaraderie with their co-workers, whom they view as a benefit of their work. They appreciate the shared passion for youth work and view their colleagues as friends. One worker stated:

I love the people that are attracted to this field. I have made so many lasting friendships. And they count in the quality and value of my life. (70, M, FT)

OST workers pointed to the opportunity to give back to the community as another main feature of the OST field $(M=3.44)$. Open-ended responses provided more evidence that OST workers value aspects of their work that contribute in meaningful ways to communities and families. Respondents ( $n=81$ ) described their commitment to helping others and specifically to making a positive difference in the lives of children and families, especially families who are underresourced and/or underserved. They expressed pride in their role in helping others, filling in gaps, and teaching youth new skills. One worker commented:

The growth and development of our children is critical to our future, and I am proud to be a part of a community of work that is focused on this. (50, F, FT)

One respondent commented that OST programs hold a complementary role to schools for children's development stating that:

I believe in the vital importance of the role OST programs play in the lives of developing school-agers; it's a "service" as critical as school . . . so every year I "re-choose" to stay [in the field]. (50, F, FT)

One respondent commented on the motivation to keep giving back to the community and children as more of a passion that can't be ignored and drives her work: "I'm getting older now so the long days are taking a toll, but I stay because I have the passion. Passion doesn't get old." (51, F, FT) 
Journal of Youth Development | http://jyd.pitt.edu/ | Vol. 15 Issue 1 DOI 10.5195/jyd.2020.821 Sustaining Passion: OST Program Workforce

Table 2. Respondents' Average Scores on Perceptions of the OST Field Organized by Degree

How true is each of the following statements about the OST field?

\begin{tabular}{|c|c|c|c|c|c|c|c|c|}
\hline \multirow[t]{2}{*}{$\begin{array}{l}\text { What is the highest level of } \\
\text { education you have } \\
\text { completed? }\end{array}$} & \multicolumn{2}{|c|}{$\begin{array}{l}\text { Associates } \\
\text { degree } \\
(n=23)\end{array}$} & \multicolumn{2}{|c|}{$\begin{array}{l}\text { Bachelor's } \\
\text { degree } \\
(n=117)\end{array}$} & \multicolumn{2}{|c|}{$\begin{array}{l}\text { Master's } \\
\text { degree } \\
(n=90)\end{array}$} & \multicolumn{2}{|c|}{$\begin{array}{c}\text { Total } \\
(n=284)\end{array}$} \\
\hline & $M$ & $S D$ & $M$ & $S D$ & $M$ & $S D$ & $M$ & $S D$ \\
\hline $\begin{array}{l}\text { Provides opportunity to work } \\
\text { with children and youth }\end{array}$ & 3.91 & 0.29 & 3.83 & 0.46 & 3.88 & 0.33 & 3.86 & 0.40 \\
\hline $\begin{array}{l}\text { Provides opportunity to give } \\
\text { back to a community }\end{array}$ & 3.48 & 0.67 & 3.42 & 0.71 & 3.54 & 0.69 & 3.44 & 0.72 \\
\hline $\begin{array}{l}\text { Provides opportunity for } \\
\text { challenging and exciting work }\end{array}$ & 3.43 & 0.73 & 3.27 & 0.74 & 3.47 & 0.69 & 3.34 & 0.73 \\
\hline $\begin{array}{l}\text { Provides a lively environment, } \\
\text { with socializing and } \\
\text { collaboration }\end{array}$ & 3.39 & 0.72 & 3.30 & 0.76 & 3.31 & 0.79 & 3.28 & 0.76 \\
\hline $\begin{array}{l}\text { Provides opportunity for } \\
\text { professional development and } \\
\text { learning }\end{array}$ & 3.22 & 0.90 & 3.06 & 0.79 & 3.14 & 0.76 & 3.08 & 0.79 \\
\hline $\begin{array}{l}\text { Provides work flexibility related } \\
\text { to days of the week and/or } \\
\text { hours at work }\end{array}$ & 2.91 & 1.04 & 2.50 & 1.03 & 2.53 & 1.06 & 2.59 & 1.03 \\
\hline $\begin{array}{l}\text { Provides opportunity for } \\
\text { advancement or promotion }\end{array}$ & 2.61 & 0.78 & 2.30 & 0.93 & 2.35 & 0.89 & 2.38 & 0.91 \\
\hline $\begin{array}{l}\text { Connects workers to benefits } \\
\text { such as health care and } \\
\text { education }\end{array}$ & 2.09 & 0.90 & 2.34 & 1.03 & 2.37 & 0.98 & 2.26 & 0.99 \\
\hline Provides fair pay & 2.35 & 0.88 & 2.18 & 1.01 & 2.24 & 0.99 & 2.24 & 0.98 \\
\hline
\end{tabular}

Note. $M=$ Mean, $S D=$ Standard deviation; 1 (Not true), 2 ( $A$ little true), 3 (Mostly true), 4 (Very true)

There was some variability in perception of features when examined by level of education. Workers with associate degrees were more likely than workers with advanced degrees to report that the OST field offers fair pay and opportunity for advancement. Across all three levels 
workers had strong agreement that the OST field offers opportunity for challenging and exciting work and a social and collaborative environment. Workers at the associate degree level and presumably earlier in their careers also perceived as "more true" that the OST field offers opportunity for professional development and learning (See Table 2).

\section{Alignment of Features of a Profession and Availability in the OST Field}

Survey respondents reported how important some typical features of a profession were to them, and also, whether or not they believed these features were evident in the OST field. Almost $90 \%$ of the respondents considered every feature presented in the survey question as important to them as employees/job seekers. Respondents attached less significance to job performance recognition and opportunity for advancement, yet still over $86 \%$ of survey participants considered those elements important. The five features considered important by the most workers were (a) life-work balance, (b) financial stability, (c) opportunity for professional development, (d) competitive pay, and (e) level of autonomy and independence. While these five features were important to the greatest number of workers, there was comparatively little confidence in the field's ability to provide financial stability or competitive pay. Respondents rated financial stability, competitive pay, and benefits as only "maybe" available in the OST field (see Table 3).

Table 3. Features of a Field of Employment and Availability in the OST Field Ranked by Percent of Respondents

\begin{tabular}{|l|c|c|c|}
\hline Element & Importance & \multicolumn{2}{|c|}{$\begin{array}{c}\text { Available in } \\
\text { OST Field? }\end{array}$} \\
\hline Life-work balance & \% Yes & N & SD \\
\hline Financial stability & 96.6 & 2.26 & 0.69 \\
\hline Opportunity for professional development & 96.3 & 1.78 & 0.62 \\
\hline Competitive pay & 95.9 & 2.45 & 0.58 \\
\hline Autonomy and independence & 95.3 & 1.88 & 0.63 \\
\hline Challenge & 93.9 & 2.43 & 0.62 \\
\hline Coaching and feedback & 93.2 & 2.58 & 0.56 \\
\hline Availability of benefits & 91.8 & 2.40 & 0.63 \\
\hline Opportunity for advancement & 90.1 & 1.99 & 0.72 \\
\hline Recognition for job performance & 88.0 & 1.96 & 0.60 \\
\hline
\end{tabular}

Note. $M=$ Mean, $S D=$ Standard deviation; 1 (No), 2 (Maybe), 3 (Definitely) 
Mean ratings on how available a feature was in the OST field varied slightly by position (ranked by mean average of all respondents). Frontline staff/practitioners ${ }^{1}$ generally gave the lowest ratings as to the availability of features, except for life-work balance and opportunity for advancement. While life-work balance and financial stability were considered important by almost every worker, those two features remained in the bottom half of mean ratings on availability in the field. Directors are the most likely workers to access full-time hours and higher salaries, yet they still rated availability of benefits comparatively lower than other features. Workers across all positions agreed that challenge was a significant feature of the OST field.

Table 4. Features of a Field of Employment and Availability in the OST Field. Organized by Position.

\begin{tabular}{|c|c|c|c|c|c|c|c|c|}
\hline & \multicolumn{2}{|c|}{$\begin{array}{l}\text { Directors } \\
(n=126)\end{array}$} & \multicolumn{2}{|c|}{$\begin{array}{l}\text { Managers/ } \\
\text { coordinators } \\
\quad(n=66)\end{array}$} & \multicolumn{2}{|c|}{$\begin{array}{c}\text { Frontline } \\
\text { staff/ } \\
\text { practitioners } \\
(n=27)\end{array}$} & \multicolumn{2}{|c|}{$\begin{array}{c}\text { Total } \\
(n=264)\end{array}$} \\
\hline & $M$ & SD & $M$ & SD & $M$ & SD & $M$ & SD \\
\hline Challenge & 2.70 & 0.48 & 2.56 & 0.56 & 2.44 & 0.64 & 2.61 & 0.54 \\
\hline Autonomy and independence & 2.47 & 0.60 & 2.46 & 0.61 & 2.33 & 0.62 & 2.45 & 0.61 \\
\hline $\begin{array}{l}\text { Opportunity for professional } \\
\text { development }\end{array}$ & 2.50 & 0.53 & 2.37 & 0.60 & 2.37 & 0.63 & 2.44 & 0.58 \\
\hline Coaching and feedback & 2.41 & 0.62 & 2.38 & 0.65 & 2.26 & 0.59 & 2.39 & 0.63 \\
\hline Recognition for job performance & 2.27 & 0.64 & 2.26 & 0.69 & 2.19 & 0.69 & 2.26 & 0.66 \\
\hline Life-work balance & 2.20 & 0.67 & 2.18 & 0.68 & 2.41 & 0.69 & 2.24 & 0.68 \\
\hline Availability of benefits & 2.05 & 0.71 & 2.08 & 0.76 & 1.89 & 0.58 & 2.01 & 0.71 \\
\hline Opportunity for advancement & 1.93 & 0.58 & 2.05 & 0.62 & 1.96 & 0.44 & 1.98 & 0.58 \\
\hline Competitive pay & 1.84 & 0.57 & 2.06 & 0.65 & 1.78 & 0.64 & 1.87 & 0.62 \\
\hline Financial stability & 1.84 & 0.63 & 1.83 & 0.67 & 1.52 & 0.51 & 1.79 & 0.63 \\
\hline
\end{tabular}

Note. $M=$ Mean, $S D=$ Standard deviation; $1($ No $), 2$ (Maybe), 3 (Definitely). Slight variation in mean ratings from Table 3 is due to small difference in number of respondents captured in Table 4 compared to Table 3.

\footnotetext{
${ }^{1}$ When coding positions we included the terms: youth development professional, teacher, educator, and specialist in the category of Frontline staff/practitioner.
} 


\section{Sustaining Passion: OST Program Workforce}

Financial concerns dominated open-ended responses when workers were asked about the challenges of working in the OST field. These concerns also seemed a major influence towards seeking employment in an alternate field. There was general consensus that working in the OST field means earning less income than earned in other fields. Many workers described tension between what they like about working in the OST field and the difficulties associated with trying to find "livable wages" which might motivate them to seek other employment:

I stay because I have been able to work my way up to a leadership role with higher pay and steadier income. If I hadn't been able to advance beyond an hourly, part-time program staff, I wouldn't still be involved. (41, F, PT)

The reality is most OST jobs do not pay a sustainable wage . . . currently the energy I get from working in OST is worth the low pay, but this may not be feasible if I decide to have my own kids, etc. $(27, \mathrm{~F}, \mathrm{FT})$

The hours overall give you time to do other things, but you have to live paycheck to paycheck which is stressful. $(30, \mathrm{~F}, \mathrm{FT})$

Responses to open-ended questions also suggest that some workers $(n=32)$ appreciate the chance to work with youth in an environment that is more autonomous and less structured than the traditional school learning environment. Respondents expressed that the field gives an opportunity to bring forth their own interests, passions, teaching style, and creativity. One worker pointed out advantages of the OST teaching environment compared to the traditional classroom:

The [OST] field is much more exciting than traditional classroom school day work. My friends who are school day teachers are very envious of our ability to adapt our lessons and programming to meet students and families as their interests and needs change over time. (36, F, FT)

While autonomy, independence, and challenge were all very important to OST workers and considered "maybe" to "definitely" available in the OST field, workers reported symptoms of overload and burnout as they strive to juggle the many demands of their jobs. These participants cited issues such as too much paperwork, high staff turnover, the stress of fundraising, changing regulations, children's behavioral issues, and the challenge of meeting the needs of so many children and families as potentially draining or overwhelming circumstances frequent in the OST field. One respondent explained: 


\section{Sustaining Passion: OST Program Workforce}

The hours, expectations, and the workload are completely unrealistic, and always changing, with-ever growing expectations, rules and regulations . . . you just can't keep up unless you're working 70 hours a week or in a larger and better supported program. (47, F, FT)

While on the survey matrix question there was comparatively higher agreement that opportunities for professional development are available in the OST field, responses to openended questions suggest that the OST field is often perceived as limited in opportunities for professional advancement and professional development. Although some directors noted that they make intentional efforts to train and mentor their staff and that this was an important and rewarding part of their jobs, others felt the lack of broad professional recognition and low remuneration was overpowering to retention.

As a director [the biggest challenge is] staff retention. The pay isn't comparable to everything you have to do for this job. This is a part-time position with fulltime commitments but we don't compensate for that. (33, F, FT)

\section{Discussion}

The study findings illuminate the significance that workers in the OST field attach to passion for a field of work, and the central importance to them of building relationships with and fostering positive and healthy development for children. However, passion alone cannot sustain a workforce. Further, there is a risk that passion can be misused, leading to extra and unpaid work (Kim, Campbell, Shepherd \& Kay, 2019; Duke University, 2019). Though the OST field can lift up passion as an asset of this particular workforce, it cannot neglect other important workforce supports, namely fair compensation, opportunities for advancement, and benefits. In other words, the OST field must work to sustain the energy and commitment to children that the OST workforce brings, and also strengthen critical foundational workforce supports.

When responding to statements about foundational workforce elements, workers were clear that financial stability, level of pay, and availability of benefits are not perceived as being widely available in the field. Research from the related field of early child care has shown that wages are still "unlivable" (Whitebook et al., 2014). In the 2005 surveys conducted by the Forum for Youth, pay was cited as the number one factor influencing youth workers to leave the field (Yohalem et al., 2010). 


\section{Sustaining Passion: OST Program Workforce}

Much work has been done over the past decade in the OST field to increase workforce supports such as training, higher education opportunities, and career pathways. The findings suggest that workers appreciate these opportunities, but have wages increased to reflect this growth? Our respondents were predominantly directors and supervisors with close to half of those respondents reporting annual salary between $\$ 20,000$ and $\$ 50,000$. It is evident that the level of wages and salary for management positions in the field needs attention. Further investigation is needed to determine how wages have shifted over time for frontline workers, and if commensurate with experience, education, and training.

Given the difficulty of raising wages in the short term and the limited budgets with which most OST programs function, it is useful for OST employers to consider alternative ways to promote satisfaction and longevity in the field. Maximizing nonmonetary benefits such as autonomy and flexibility might help to decrease staff burnout and turnover. Addressing the desire to "give back to a community" by intentionally promoting and supporting connections between workers and the families and communities they serve may help to grow aspirations towards leadership in the field and staying power. The results show that work-life balance is greatly important, but under-experienced. Finding ways to increase recognition of job performance by creating a deeper culture of gratitude and appreciation for work accomplishments may promote longevity in the field.

It was curious that workers from all levels agreed that "challenge" was a significant feature of the OST field. It's impossible to know the specific type of challenge that workers had in mindwe surmised it was likely the daily challenge of managing large and vibrant groups of children and youth, the stress of creating and delivering engaging and interesting experiences often at the end of a long school day while also managing children's powerful emotions, trauma, relationships, and growing experiences. The evidence seems in, that working in the OST field is physically and emotionally exhausting, yet OST workers continue to exude passion. How does the field respond to this truth?

The education and years of service profile of workers in this exploratory study resembled data from the 2013 NAA findings which showed 34\% having a master's degree or higher and an average of 10 years in the field (NAA, n.d.). Both survey samples, however, were overpopulated with director and supervisor level respondents. There is clearly a need for additional research on the frontline population of workers to gain a more comprehensive profile of the workforce and to inform strategies to support retention. 


\section{Limitations}

This exploratory survey study was limited in several ways. Across many dimensions the sample of survey respondents is not fully representative of the diversity in the workforce population that would reflect our understanding and experience of the field. The invitation to the survey was most likely received by a program leader based on the original distribution list. Those leaders may have been unlikely to pass the survey on to frontline staff which resulted in the overrepresentation of managers and supervisors in the survey sample. Program managers may also be those most likely to have the access and time to complete a survey during the work hours.

\section{Conclusion}

Future, larger-scale surveys should make intentional efforts to reach frontline staff and a more diverse national population. We consider the continued investigation of OST worker background, experience, perceptions of, and persistence in the field to be critical to the quality of OST learning and growing experiences for children and youth.

\section{References}

Aspen Institute. The National Commission on Social, Emotional, and Academic Development. (2019). From a nation at risk to a nation at hope. Retrieved May 1, 2019 from https://www.aspeninstitute.org/programs/national-commission-on-social-emotional-andacademic-development/

Commission on Children at Risk. (2003). Hardwired to connect: The new scientific case for authoritative communities. New York: Institute for American Values.

Curry, C., Qaqish, B., Carpenter-Williams, J., Eckles, F., Mattingly, M., Stuart, C., \& Thomas, D. (2009). A national certification exam for child and youth care workers: Preliminary results of a validation study. Journal of Child and Youth Care Work, 22, 152-170.

Duke University. (2019). Love your job? Someone may be taking advantage of you. Retrieved May 29, 2019 from https://phys.org/news/2019-05-job-advantage.html

Elliot, M., Fairweather, I., Olsen, W., \& Pampaka, M. (2016). A dictionary of social research methods. Oxford, UK: Oxford University Press.

Gable, S., \& Halliburton, A. (2003). Barriers to child care providers' professional development. Child and Youth Care Forum, 32, 175-193. https://doi.org/10.1023/A:1023300609394 
Journal of Youth Development | http://jyd.pitt.edu/ | Vol. 15 Issue 1 DOI 10.5195/jyd.2020.821 Sustaining Passion: OST Program Workforce

Kim, J. Y., Campbell, T. H., Shepherd, S., \& Kay, A. C. (2019). Understanding contemporary forms of exploitation: Attributions of passion serve to legitimize the poor treatment of workers. Journal of Personality and Social Psychology. Retrieved May 1, 2019 from https://www.ncbi.nlm.nih.gov/pubmed/30998042

Knoche, L., Peterson, C. A., Edwards, C. P., \& Jeon, H. J. (2006). Child care for children with and without disabilities: The provider, observer, and parent perspectives. Early Childhood Research Quarterly, 21(1), 93-109. https://doi.org/10.1016/j.ecresq.2006.01.001

Miller, B. M., \& Hall, G. (2007). What counts in after school? Findings from the Massachusetts afterschool research study (MARS). Journal of Youth Development, 1(3), 98-114. https://doi.org/10.5195/jyd.2007.378

Morrow, M.W. (2000). Lifers and leavers: A comparison of school-age care practitioners who remain in the field and those who leave (Unpublished master's thesis). Concordia University, Saint Paul, MN.

National AfterSchool Association. (n.d.). Promoting professionalism. (In a series of focus briefs: The state of afterschool quality). Retrieved May 1, 2019 from https://naaweb.org/images/final NAA 3 F.pdf

Nee, J., Howe, P., Schmidt, C., \& Cole, P. (2006). Understanding the afterschool workforce: Opportunities and challenges for an emerging profession. Oakton, VA: National AfterSchool Association.

Porter, N. (2012). High turnover among early childhood educators in the United States. Retrieved May 1, 2019 from https://www.childresearch.net/projects/ecec/2012 04.html

Whitebook, M. (1989). Who cares? Child care teachers and the quality of care in America. Final Report, National Child Care Staffing Study. Retrieved April 3, 2019 from https://cscce.berkeley.edu/files/1990/Who-Cares-full-report.pdf

Whitebook, M., Phillips, D., \& Howes, C. (2014). Worthy work, still unlivable wages: The early childhood workforce 25 years after the national child care staffing study. Center for the Study of Child Care Employment, University of California, Berkeley.

Yohalem, N., \& Pittman, K. (2006). Putting youth work on the map: Key findings and implications from two major workforce studies. Washington, DC: Forum for Youth Investment for the Next Generation Workforce Coalition.

Yohalem, N., Pittman, K., \& Edwards, S. (2010). Strengthening the youth development/after-school workforce. Retrieved May 1, 2019 from https://youtheconomicopportunities.org/sites/default/files/uploads/resource/Strengthening the $Y$ D-AS Workforce.pdf 